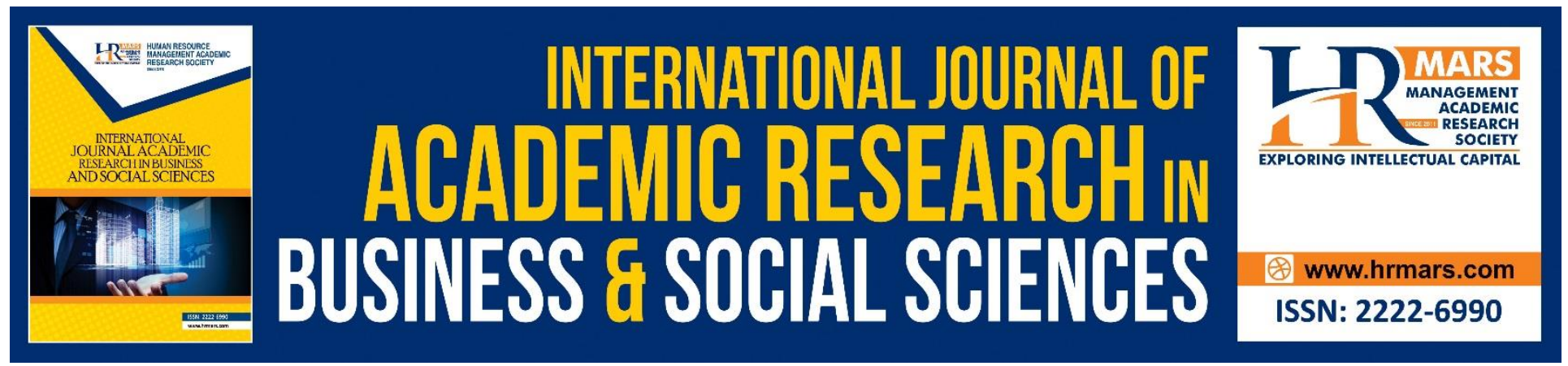

\title{
Factors Influencing Employee Turnover in the Food Manufacturing Industry in Malaysia
}

\section{Ong Choon Hee and Yee Shann Ann}

To Link this Article: http://dx.doi.org/10.6007/IJARBSS/v9-i1/5423

DOI: $\quad 10.6007 /$ IJARBSS/v9-i1/5423

Received: 15 Dec 2018, Revised: 28 Jan 2019, Accepted: 07 Feb 2019

Published Online: 13 Feb 2019

In-Text Citation: (Hee \& Ann, 2019)

To Cite this Article: Hee, O. C., \& Ann, Y. S. (2019). Factors Influencing Employee Turnover in the Food Manufacturing Industry in Malaysia. International Journal of Academic Research in Business and Social Sciences, 9(1), 482-491.

\section{Copyright: (C) 2019 The Author(s)}

Published by Human Resource Management Academic Research Society (www.hrmars.com) This article is published under the Creative Commons Attribution (CC BY 4.0) license. Anyone may reproduce, distribute, translate and create derivative works of this article (for both commercial and non-commercial purposes), subject to full attribution to the original publication and authors. The full terms of this license may be seen at: http://creativecommons.org/licences/by/4.0/legalcode

$$
\text { Vol. 9, No. 1, 2019, Pg. } 482 \text { - } 491
$$

Full Terms \& Conditions of access and use can be found at http://hrmars.com/index.php/pages/detail/publication-ethics 


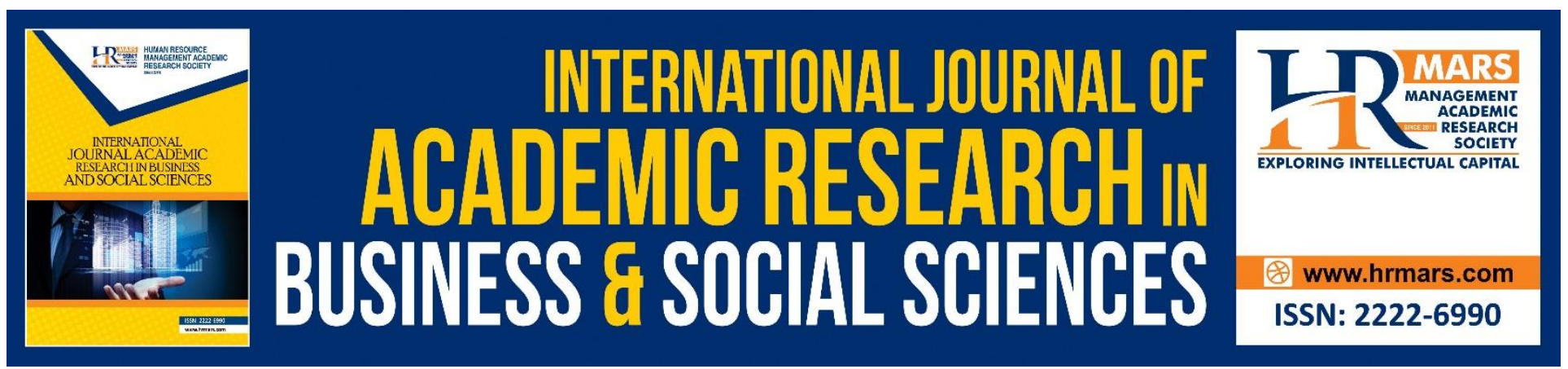

\title{
Factors Influencing Employee Turnover in the Food Manufacturing Industry in Malaysia
}

\author{
Ong Choon Hee and Yee Shann Ann \\ Azman Hashim International Business School, Universiti Teknologi Malaysia, Johor, Malaysia. \\ Corresponding Author: ongchoonhee@gmail.com
}

\begin{abstract}
The purpose of this paper is to share the importance of employee turnover and factors that contribute to employee turnover. It is recommended in this study that compensation and benefits, work-life balance, work stress and job satisfaction are important factors that influence employee turnover. This study also provides research implications to guide industry practitioners in the aspect of employee turnover. This study serves as a guideline to support food manufacturing industry in restructuring its corporate policies in human resource to sustain its business and retain employees. In addition, this research is expected to be a reference for future research regarding employee turnover management.
\end{abstract}

Keywords: Employee Turnover, Compensation and Benefits, Work-Life Balance, Work Stress, Job Satisfaction.

\section{Introduction}

Employees are the backbone of the industry and essential human asset for organizations to operate smoothly. Organizations require employees to apply their personal abilities in their works and deliver the best performance to drive the company towards achieving its objectives and goals. However, one of the challenges that organizations have to face is employee turnover. The situation of employees leaving an organization and has to be replaced by someone else is known as employee turnover (Abdul Latif and Saraih, 2016). In Malaysia, issues of employee turnover had been surfaced since early 1991 and gradually increase owing to high demand of workforce and better opportunities in the market (Keni et al., 2013). Hewitt Associates Total Compensation Management Survey reported that the turnover rate in Malaysia has undergone an increasing trend from 9.3 percent in year 2009 to 10.1 percent in year 2010. Lately, the findings from General Industry Total Rewards Survey in 2013 showed that employee turnover rate in the Malaysian general industry experienced an increment from year 2012 with 12.3 percent to 13.2 percent in year 2013 (Tower Watson, 2013). In fact, the manufacturing industry $(24.0 \%)$ recorded higher employee turnover, followed by conglomerates $(14.0 \%)$ and financial services sectors (13.3\%). One of the main reasons for high turnover rate in the 
Malaysian industry is that employees believe the country economy would remain stable even though there are uncertainties in the global economy (Tower Watson, 2013). In the context of food manufacturing industry in Malaysia, it plays a critical role in contributing towards domestic economy growth. Other than value-added process for primary agricultural products and expanding export market, food manufacturing industry also serves as a source of employment (Ahmed, 2012). According to MIDA (2014), there are more than 3,200 establishments of food manufacturers which formed by more than 80 percent of small and medium enterprises (SME) and predominantly Malaysian-owned establishments. In Malaysia, food processing contributed about $10 \%$ to the total manufacturing output. Malaysia Gross Domestic Product (GDP) in 2017 was recorded as 5.2 percent and expected to achieve 5.4 in 2018 based on the forecast raised by The World Bank as reported in New Straits Times, April 12, 2018. The favourable economic condition promotes the increase of both domestic and foreign investments, and further boost the labour market for continuous growth. Based on the findings in Annual Survey of Manufacturing Industries, 2010, the total employment of manufacturing of food products in 2009 was recorded at 4.2 percent of the total employment in overall manufacturing sector. In Johor state, the total employment in manufacturing sector in 2009 was 19.5 percent of the total employment. In 2009, the gross output in manufacture of food products contributed 21.6 percent of the total gross output in Johor state (Department of Statistics Malaysia, 2017). The food manufacturing industry is moving towards more capital-intensive operations and expanded into higher value-added production. Therefore, there is a need to employ a large number of food technologists, chemists, nutritionists and skilled workers to handle the machines as well as fulfilling the international requirements on food safety and quality (Ministry of International Trade and Industry, 2018). Besides training facilities, skilled and young workforce were the greater gear enabled food manufacturing industry to grow and expand (Malaysian Investment Development Authority, 2017). Under such circumstances, the competition for recruitment and retention of talents has become intensive in the Malaysian industrial sector. This was evident as mentioned by one of the panellists at the Global Business Services Forum 2017, the average turnover for any individual is 2.5 years in recent years. From the perspective of human resource management, high turnover rate is a serious issue where it involves financial consequences, affects company productivity and performance, company reputation and image. In addition, according to a study conducted by the Human Resources Management Association, employers usually end up spending six to nine months of staff salaries to recruit, select and train the new hires. The MEF Survey on Management of Foreign Workers conducted a survey among employers, indicated that high turnover rate of local employees is urging them to move their interest in recruiting foreign workers, as they have lower chance in changing job (Malaysia Employers Federation, 2016). Therefore, it is crucial for organizations to identify and understand the factors that contribute to employee turnover, especially in food manufacturing industry. There were several researchers studied employee turnover issues in different industry in Malaysia. Those studies mostly examine the relationship between factors such as pay, training, supervisors, job satisfaction, job stress, organizational culture and turnover intention (Choong et al., 2013). There were also researchers studied employee turnover among Millennials (Choong et al., 2013) in the electrical and electronic industries. Those studies showed that the high employee turnover was mainly related to low pay and low satisfaction among employees. Nevertheless, the present research intend to focus on understanding employee turnover in the food 
INTERNATIONAL JOURNAL OF ACADEMIC RESEARCH IN BUSINESS AND SOCIAL SCIENCES

Vol. 9, No. 1, Jan, 2019, E-ISSN: 2222-6990 @ 2019 HRMARS

manufacturing industry with identified factors such as compensation and benefits, work-life balance, work stress and job satisfaction.

\section{Employee Turnover}

Employee turnover can be described as employees are going to leave an organization and new employees are required to fill up the vacancies. A similar definition provided by Harkins (1998) is that the "entrance of new employees into the organization and the departure of existing employees from the organization". Employee turnover can be categorized as internal and external turnover. Internal turnover refers to one employee is taking over a new task in the same company, whereas external turnover indicates employees left the company for another job in other company. Therefore, internal turnover contributes less harm to the organization by saving the cost of recruitment. Another differentiation of employee turnover is voluntary turnover and involuntary turnover. Voluntary turnover implies when the employee decides to leave the company with own intention, while involuntary turnover denotes the employee has to leave the company due to certain unforeseen circumstances such as long-term sickness, layoff and termination. In the Malaysian context, employee turnover rate in general industry has experienced an elevating trend from 2012 (12.3\%) to $2013(13.2 \%)$ and the percentage keeps on increasing in the later years (Tower Watson, 2013). The number gives a pressing challenge to the human resource managers in Malaysia when recruiting and retaining workforce for the organization. There are several factors and consequences that play significant roles in influencing employee's turnover rate of an organization. Previous studies have found that factors led to employee's turnover include job satisfaction, wages, career promotion, benefits and packages, supervisors, job fit, individuality, work culture and opportunity for training (Arokiasamy, 2013; Choong et al., 2013). The consequences of high turnover rate include high direct and indirect cost incurred, loss of productivity, impact to company's reputation and performance. Global Business Articles Website in 2010 has mentioned that turnover cost for a middle level employee is estimated at 150 percent of the annual salary and up to 400 percent for a specialized high-level employee. The cost mainly spent in new recruitment process such as administrative expenses, advertising job vacancies, screening of candidates, selecting and medical check-up expenses. Moreover, productivity of the organization will be affected with employee turnover. Loss of productivity is generally due to the tedious processes in getting new employees such as recruitment, selection, training and placement for the job. During the process, co-workers may require to spend additional time to guide and assist the newly hired employees before they can handle the task well. On the other hand, frequent recruitment of new employees and posting of job vacancies give a poor image to the company. This is owing to the tendency that public tends to perceive a company as problematic when employees are not willing to stay long in the company.

\section{Compensation and Benefits}

Compensation refers to the cumulative financial and non-financial rewards payable to employees in return for their contribution to the organization (Mondy and Noe, 2005). The amount of these rewards is usually based on the individual work value, contribution level, effort paid in job and overall performance in the organization (Milkovich and Newman, 2005). In fact, the compensation system has traditionally been designed for the purpose of retaining employees and motivating them to 
elevate their efforts putting in job, hence creating output in achieving organizational goals (Bergmann and Scarpello, 2001). In general, compensation can be in the form of basic salary or allowance, incentive and bonuses (American Compensation Association, 1995). Moreover, compensation is categorised into direct compensation and indirect compensation. Direct compensation includes salaries, wages, bonuses or commission, whereas indirect compensation refers to incentives, medical claims, housing allowance, hospitalization allowance, vehicle loan allowance, annual leave allowance and training opportunities. Benefits refer to indirect rewards in non-financial form given to an employee as part of the organizational membership where it plays a role in motivating and retaining of employees. Benefits could be in the form of work recognition, word praise, opportunities on career advancement as well as best employee award. Nowadays, organization with better benefits program has become more attractive as people are looking at benefits provided by the organization other than salary. The reason being is that benefits are critical in influencing individual's motivation and job satisfaction. Many organizations not only use benefits to reward and recognize their employee's efforts and contributions, but use it as a motivational tool to increase employee's productivity via improving job satisfaction level (Lee and Mitchell, 1994). Since compensation and benefits are tools in human resource management and have direct influence on employee's satisfaction and performance, it is essential for the top management to design a practicable compensation and benefits program in the organization (Osibanjo et al., 2014). The power of compensation together with benefits cannot be neglected as most of the studies have proven that the negative impacts of compensation may lead to significant dissatisfaction among employees and difficulty in employee retention. Similarly, the study from Osibanjo et al. (2014) reported that employee retention is positively and significantly related to compensation. In other words, if an organization fails to provide equitable compensation to the employees, it would result the establishment of negative attitude towards the organization and consequently causing the employees to leave the organization. Therefore, based on the above discussion, it is proposed that:

Proposition 1: Compensation and benefits have a significant relationship with employee turnover.

\section{Work-Life Balance}

Work-life balance signifies the extent to which an employee experiences satisfaction and meet their work and non-work needs in life (Alison \& Rosalie, 2015). The agreed definition of the term work-life balance has proven elusive even though it is widely used. In the review of the meaning of work-life balance by Kalliath and Brough (2008), it is suggested that work-life balance is defined as individual perception of the work and non-work activities which promote growth in accordance with an individual's current life priorities. In recent times, work-life balance is getting more concern and widely studied by researchers. Work-life balance reflects the equality of work and life portion in an individual's daily life. There is no one agreed definition for work-life balance. According to Amram (2004), work-life balance can be described as perceiving employees have achieved a realistic and personal satisfying state among different key functions in their life or better known as family, work and leisure. The role of work-life balance has direct linkage with employee turnover where it influences employee decision making either to stay or leave the organization (Deery, 2008). Today, the younger generation occupied most of the positions in the market and being recognized as the 
main workforce in Malaysia. The living style of the younger generation has changed. Work is not the main focus in their life, whereby they are looking for other activities such as family gathering, community activities, voluntary works, leisure holidays, personal development and recreation to make their life more contented and lively. Broers (2005) believed that balancing successful careers with personal and family life can be challenging and can affect individuals' satisfaction in work and life roles. Therefore, based on the above rationale, it is proposed that:

Proposition 2: Work-life balance has a significant relationship with employee turnover.

\section{Work Stress}

Stress is defined as a situation in which individual realizes the pressure on them till not able to handle it (Mansoor et al., 2011). Work stress is the reaction towards the pressure employees faced in work (Kwartier, 2015). The most generic definition of stress was proposed by Selye (1975) as non-specific response of the body to any demand. Work stress is always linked with work pressure received by an individual when performing job task or dealing with people in the organization. Work pressure refers to the pressure experienced at the workplace when specific task is needed to complete specifically within the timeframe (Kwartier, 2015). However, high pressure in work is likely linked to employee's work stress. Researchers have conducted studies on work stress or job stress in different industries and factors that influence it had been identified. The most significant factors were role ambiguity, role conflict and role overload which directly contribute to employee's stress in the workplace. Role ambiguity means the individual feels that job obligation is not clearly stated and mentioned in a direct manner and caused uncertainty to them (Glissmeyer et al., 2008). According to Beehr et al. (1976), Cordes and Dougherty (1993), and Dyer and Quine (1998), role ambiguity present when an individual is lacking of information about the requirements of his or her role, how to perform the role, and how the role is being successfully done according to the expectation. Role ambiguity is able to lead to negative outcomes in an individual due to loss of confidence, feeling of uncertainty, anxiety and depression (Muchinsky, 1997). On the other hand, role conflict is referred to as the incompatible requirements on an individual such as multiple roles occupied by a single individual would cause negative emotional reactions and unable to handle works. When a person's role expectations differ from the expectations of the management, role conflict will occur. Generally, role conflict is likely to happen in any industry if the management is giving misleading information to the employees and their superior. Furthermore, role overload is also a critical issue that contributes to work stress. Role overload is defined as an individual is required to complete tremendous amount of work in his or her role. Employees tend to feel stressful when the workload is exceeding their ability to complete it within the stipulated normal working hours. Thus, work overstress tends to cause errors in work done and increase the tendency of employee turnover (Choong et al., 2013). Therefore, it is proposed that:

Proposition 3: Work stress has a significant relationship with employee turnover.

\section{Job Satisfaction}

Job satisfaction has a close relationship with turnover or resignation. According to Locke (1976), the widely used definition of job satisfaction in research is a "pleasurable or positive emotional state 
causing from the evaluation of individual's work or working experiences". The emotions of the employees can affect their working behaviours. Gibson et al. (2000) defined job satisfaction as an individual expression of personal well-being related to job performance. Baron and Greenberg (2003) explained that job satisfaction is a general attitude towards job and the affective, cognitive and evaluative reactions of the job performed. Nevertheless, job satisfaction refers to the degree of contentment in the individual with the reward he or she receives from intrinsic motivation at work. Basically, job satisfaction can be described as the feeling of fulfilment of employees when they perform well in the job and being recognized by the employers. It is essential to increase the feeling of contentment and fulfilment in every employee in the organization so that group productivity and performance will be improved indirectly. Employee with high job satisfaction tends to have positive attitude towards the task given and able to perform at their best level. In contrast, low job satisfaction employees maybe inactive and passive towards their job performance and do not willing to put effort to complete the task. There are several conditions that keep people satisfied at work, for instance salary, colleagues, working environment, organizational culture and etc. (Arokiasamy, 2013). According to Thwala et al. (2012), factors that influence job satisfaction include compensation, recognition, training opportunity, relationship with colleagues as well as challenges at work. Ganesan (2010) has pointed out the most common factors influence job satisfaction are pay, promotion, work content and supervision. If job satisfaction is high, it will decrease employee turnover rate in return. Therefore, it is evident that there is a significant and negative relationship between job satisfaction and employee turnover (Ganesan, 2010). Hence, it is proposed that:

Proposition 4: Job satisfaction has a significant relationship with employee turnover.

\section{Theoretical Framework}

Based on the above findings, the dependent variable in this study is employee turnover, whereas compensation and benefits, work-life balance, work stress, and job satisfaction are the independent variables that affect employee turnover in the food manufacturing industry. The proposed theoretical framework is shown in Figure 1.

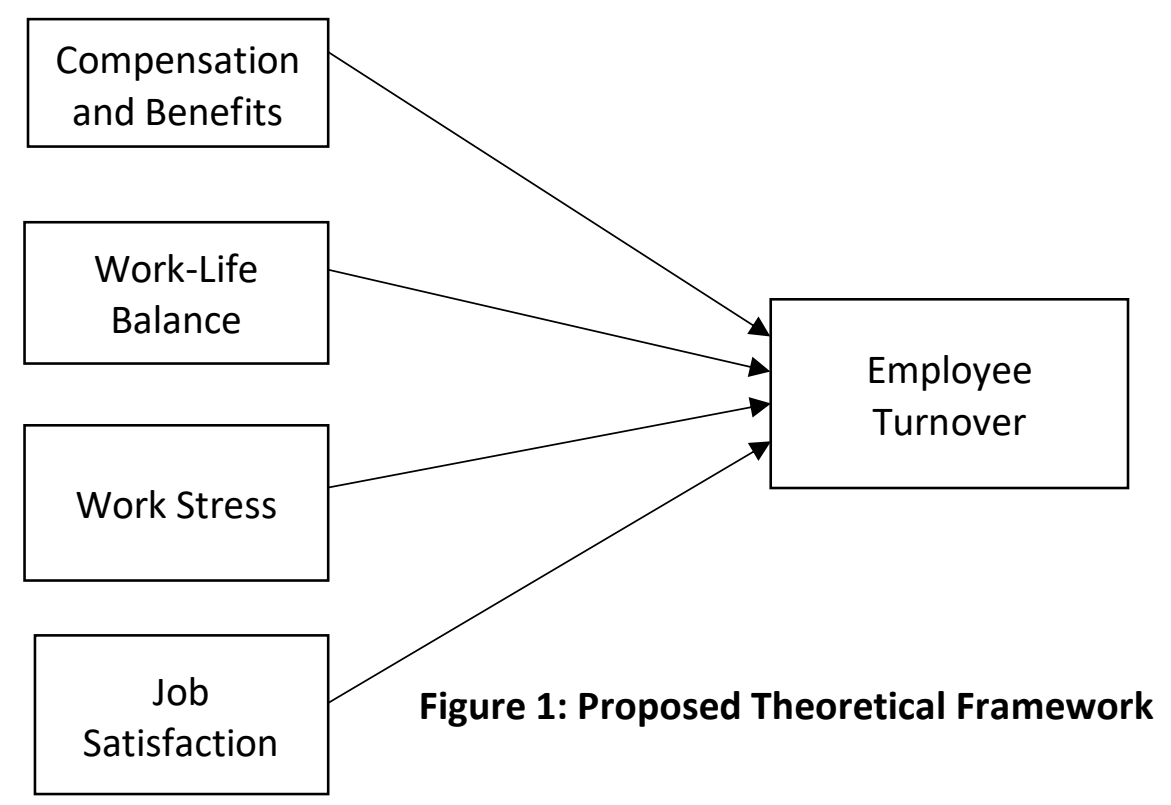




\section{Research Implications}

This research provides the food manufacturing industry an overview on factors influence employee turnover. There are several factors causing the workforce turnover within the same industry or switch to different industries. The finding of this research is expected to enable the management of food manufacturer in identifying the actual reasons of the employee turnover in the organisation. From this research, significant factors that contribute to turnover will be identified based on the data collected and analysis results. It is believed that employers can use the findings and recommendations to solve employee turnover issues with the most suitable approaches. Furthermore, the findings of this study will raise awareness among employers to initiate preventive actions in order to prevent recurrence of turnover issues. Recruitment and selection costs are generally high to an organization. Therefore, the outcome of this research may assist employers to initiate control measures and solutions to tackle employee turnover issues. By looking into the critical issues in the organization, employer can plan human resource strategies in a more precise manner and eventually strengthen the relationship between employer and employees. The practical implications generated from this study will support food manufacturing industry in restructuring its human resource and corporate policies to sustain its business and retain the employees. Finally, this research project is expected to serve as a reference for future research in relation to employee turnover management.

\section{Conclusion}

High turnover rate may cause several consequences to an organization. First of all, organizations have to allocate additional expenses in recruiting, selecting and training new employees to replace those who left the company. Replacing a full-time worker is estimated to incur 25 percent of the individual total annual compensation. Moreover, company's productivity and performance may be affected by high turnover rate. As a result, organizations might lose their competitiveness in the market. Therefore, putting effort in identifying factors that influence high turnover has to be done before applying employee retention strategies. Having noted the consequences of employee turnover in the food manufacturing industry, it is necessary to conduct a study to address the issues and recommend ways to overcome the undesired outcome.

\section{Acknowledgements}

The authors would like to thank the Malaysian Ministry of Higher Education and Universiti Teknologi Malaysia (GUP-Vot: 14J81) for providing financial support to publish this paper.

\section{References}

Abdul Latif, F. D. \& Saraih, U.N. (2016). Factors Influencing Employee Turnover in Private Sector in Malaysia: A Concept Paper. Australian Journal of Basic and Applied Sciences, 10(7), 51-55.

Ahmed, E.M. (2012). Malaysia's Food Manufacturing Industries Productivity Determinants. Modern Economy, 3, 444-453.

Alison, A.R. and Rosalie, J.H. (2015). Work-Life Balance. Society for Industrial and Organizational Psychology. 
INTERNATIONAL JOURNAL OF ACADEMIC RESEARCH IN BUSINESS AND SOCIAL SCIENCES

Vol. 9, No. 1, Jan, 2019, E-ISSN: 2222-6990 (C) 2019 HRMARS

American Compensation Association (ACA). (1995). Catalogue of Compensation and Benefits Certification and Training Seminars. Personnel Journal, 74(1), 16.

Amram, S. (2004). Organizational Work Life Balance Practices: Socialization, Perceived Fit and Organizational Outcomes. Concordia University, Montreal, Quebec, Canada.

Arokiasamy, A.R.A. (2013). A Qualitative Study on Causes and Effects of Employee Turnover in the Private Sector in Malaysia. Middle-East Journal of Scientific Research, 16(11), 1532-1541.

Baron, R.A. and Greenberg, R.A. (2003). Behavior in organizations, 8th ed. Upper Saddle River, NJ: Prentice-Hall.

Beehr, T.A., Walsh, J.T., and Taber, T.D. (1976). Perceived situational moderators of the relationship between subjective role ambiguity and role strain. Journal of Applied Psychology, 61, 35-40.

Bergmann, T. J. and Scarpello, V. G. (2001) Compensation Decision Making (4th ed.). Harcourt, Fort Worth, TX.

Broers, C.M. (2005). Career and Family: The Role of Social Support. Griffith University, PhD Thesis.

Choong, S.N., Leong, C.J., Leong, W.X., Loh, F.Y. and Teo, K.L. (2013). A Study of Employees' Turnover Intention among Generation $Y$ in Fast-Food Industry. Bachelor's degree, Univeristi Tunku Abdul Rahman, Kuala Lumpur.

Cordes, C.L. and Dougherty, T.W. (1993). A review and integration of research on job burnout. Academy of Management Review, 18, 621-656.

Deery, M. (2008). Talent Management, Work-Life Balance and Retention Strategies. International Journal of Contemporary Hospitality Management. 20(7), 792-806.

Department of Statistics Malaysia. (2017). Report on the Annual Survey of Manufacturing Industries, 2010. Retrieved on May 20, 2018, from https://www.dosm.gov.my/v1/index.php?r=column/ctheme\&menu id=SjgwNXdiM0 J IT3Q2TDBIWXdKdUVIdz09\&bul_id=TEROanZBQIJ2QjhEVzcvVzI4V3NOdz09

Dyer, S. and Quine, L. (1998). Predictor of job satisfaction and burnout among the direct care staff of a community learning disability service. Journal of Applied Research in Intellectual Disabilities, 11(4), 320-332.

Ganesan. S. (2010). Job satisfaction and turnover intention among private sector employees in Kedah, Malaysia. Master of Science Management.

Gibson, J.L., Ivancevich, J.M., and Donnelly, J.H. (2000). Organizations: Behaviour, Structure, Processes. 10th ed. Boston: McGraw-Hill.

Glissmeyer, M., Bishop, J.W. and Fass, R.D. (2008). Role conflict, role ambiguity and intention to quit the organization: The case of law enforcement. Academic Management Journal, 40(1), 82111.

Harkins, P.J. (1998). Why Employees Stay or Go. Workforce. 77(10), 74-78.

Kalliath, T. \& Brough, P. (2008). Work-Life Balance: A review of the meaning of the balance construct. Journal of Management \& Organization, 14(03), 323-327.

Keni, Rajendran Muthuveloo, Teoh, A.P. and Rubiah Ab Rahman, (2013). Turnover intention trend among commercial banks in Penang, Malaysia. International Conference on Entrepreneurship and Business Management. pp: 21-22. 
INTERNATIONAL JOURNAL OF ACADEMIC RESEARCH IN BUSINESS AND SOCIAL SCIENCES

Vol. 9, No. 1, Jan, 2019, E-ISSN: 2222-6990 @ 2019 HRMARS

Kwartier, M. (2015). Is work stress the same as work pressure? 15Minutes4Me.com. Retrieved on June 12, 2018, from https://www.15minutes4me.com/stress-free/is-work-stress-the-same-aswork-pressure/

Lee, T.W. and Mitchell, T.R. (1994). An alternative Approach: The unfolding Model of Voluntary Employee Turnover. Academy of Management Review. 12, 51-89.

Locke, E.A. (1976). The nature and causes of job satisfaction. In M. D. Dunnette (Ed.), Handbook of industrial and organizational psychology. Chicago: Rand McNally. pp. 1297-1349.

Malaysian Employers Federation (MEF). (2016). Employers Grant Lower Salary Increases and Bonuses. MEF Press Release. Retrieved on May 20, 2018, from http://www.mef.org.my/news/pr_article.aspx?@ID=19

Malaysian Investment Development Authority (MIDA). (2014). Investment Opportunities in Food Technology in Malaysia. Retrieved on June 5, 2018, from http://www.mida.gov.my/env3/uploads/events/Jan2015/MIDA.pdf

Malaysian Investment Development Authority (MIDA). (2017). Food Industry in Malaysia. Retrieved on May 20, 2018, from http://www.mida.gov.my/home/33/pages/

Mansoor, M., Fida, S., Nasir, S. \& Ahmad, Z. (2011). The Impact of Job Stress on Employee Job Satisfaction A Study on Telecommunication Sector of Pakistan. Journal of Business Studies Quarterly, 2(3), 50-56.

Milkovich, G. T. and Newman, J. M. (2005) Compensation (8th ed.). McGraw-Hill: Boston.

Mondy, R. W. and Noe, R. M. (2005). Human Resource Management (9th ed.). Pearson Education: New Jersey.

Muchinsky, P. (1997). Psychology applied to work: An introduction to industrial and organizational psychology (5th ed.). Pacific Grove, CA: Brookes/Core Publishers.

Osibanjo, O.A., Adeniji, A.A., Falola, H.O. and Heirsmac, P.T. (2014). Compensation Packages: A Strategic Tool for Employees' Performance and Retention. Leonardo Journal of Sciences, 25, 65-84.

Selye, H. (1975). Confusion and controversy in the stress field. Journal of Human Stress, 1, 37-44.

Thwala, D.W., Ajagbe, A.M., Long, C.S., Bilau, A.A. and Enegbuma, W.I. (2012). Sudanese Small and Medium Sized Construction Firms: An Empirical Survey of Job Turnover. Journal of Basic, Applied Social Research JBASR, in press.

Watson, T. (2013). 2013 General Industry Total Rewards Survey. Retrieved on May 23, 2018, from https://www.towerswatson.com/en-MY/Press/2013/10/Higher-turnover-rate-in-Malaysianfinancial-Services-industry 